DOI: https://doi.org/10.24127/ajpm.v10i3.3789

\title{
MODEL PEMBELAJARAN DARING DENGAN PENDAMPINGAN ORANG TUA
}

\author{
Andy Sapta ${ }^{1^{*}}$, Abdul Hamid ${ }^{2}$, Edi Syahputra ${ }^{3}$ \\ ${ }^{1 *}$ Sekolah Tinggi Manajemen Informatika dan Komputer Royal, Kisaran, Indonesia \\ ${ }^{2,3}$ Universitas Negeri Medan, Medan, Indonesia \\ *Corresponding author \\ E-mail: saptaandy@gmail.com ${ }^{1 *)}$
}

Received 07 June 2021; Received in revised form 13 September 2021; Accepted 27 September 2021

\begin{abstract}
Abstrak
Tujuan penelitian ini adalah untuk mengembangkan model pembelajaran daring dengan pendampingan orang tua yang layak digunakan bagi siswa kelas VII SMP Negeri di kota Kisaran. Populasi pada penelitian ini adalah seluruh siswa kelas VII (tujuh) SMP Negeri di Kisaran pada tahun ajaran 2019/2020. Adapun langkah-langkah (sintaks) model pembelajaran ini adalah model pembelajaran SAPTA, yaitu sebagai berikut: (1) Schedule (fase perancangan pembelajaran); (2) Acceptance (fase umpan balik); (3) Performance (fase penugasan); (4) Transmit (fase penyampaian informasi); (5) Assistance (fase pendampingan orang tua). Instrumen penelitian ini terdiri dari angket dan hasil belajar siswa. Dalam penelitian menggunakan teknik analisis data guna mengetahui validitas, kelayakan, keefektifan, dan praktikalitas model pembelajaran. Penelitian ini menghasilkan model pembelajaran daring dengan pendampingan orang tua beserta perangkat pendukungnya yang layak diimplementasikan untuk mendukung kegiatan pembelajaran terutama pembelajaran daring. Perangkat pembelajaran yang dihasilkan adalah aplikasi android pendampingan orang tua dalam belajar, buku model, buku panduan guru, dan buku panduan orang tua. Melalui penelitian ini juga telah dibuktikan bahwa produk yang dikembangkan memberikan dampak yang positif, yaitu dapat meningkatkan pencapaian hasil belajar mandiri siswa secara signifikan. Dapat disimpulkan model pembelajaran daring dengan pendampingan orang tua yang dikembangkan dinilai layak, efektif, dan praktis digunakan bagi siswa kelas VII SMP Negeri di kota Kisaran.
\end{abstract}

Kata kunci: Android; orang tua; pembelajaran daring.

\begin{abstract}
This study aims to develop an online learning model with parental assistance that is suitable for use for seventh-grade students of SMP Negeri in Kisaran city. The population in this study were all grade VII (seven) public junior high school students in Kisaran in the 2019/2020 school year. The steps (syntax) of this learning model are the SAPTA learning model, as follows: (1) Schedule (learning design phase); (2) Acceptance (feedback phase); (3) Performance (assignment phase); (4) Transmit (information delivery phase); (5) Assistance (parental assistance phase). The research instrument consisted of a questionnaire and student learning outcomes. The research uses data analysis techniques to determine the learning model's validity, feasibility, effectiveness, and practicality. This research produces an online learning model with parental assistance and its supporting devices that can be implemented to support learning activities, especially online learning. The resulting learning devices are an android application to assist parents in learning, model books, teacher manuals, and parent manuals. Through this research, it has also been proven that the product developed has a positive impact. Namely, it can significantly increase the achievement of students' independent learning outcomes. It can be concluded that the online learning model with parental assistance that was developed is considered feasible, effective, and practical to use for grade VII students of SMP Negeri in Kisaran city.
\end{abstract}

Keywords: Android; online learning; parents.

This is an open access article under the Creative Commons Attribution 4.0 International License 
DOI: https://doi.org/10.24127/ajpm.v10i3.3789

\section{PENDAHULUAN}

Guru sebagai tenaga pendidik selalu berusaha untuk melaksanakan tanggung jawabnya dalam menghasilkan siswa yang lebih baik. Dalam melaksanakan tugasnya, guru mengajar dengan menerapkan metode pembelajaran dan menggunakan media pembelajaran yang dianggap mampu membantu siswa dalam menyerap materi pelajaran. Dalam pembelajaran daring di era Covid-19, banyak teknik pembelajaran yang dilaksanakan oleh guru dalam memberikan pembelajaran daring.

Pada masa pandemi pembelajaran dilakukan dengan menggunakan daring. Pembelajaran daring dengan menggunakan aplikasi yang cukup familiar, seperti google classroom, edmodo, whatsapp group, telegram. Penggunaan aplikasi ini tidak dapat sepenuhnya mendukung proses pembelajaran. Banyak hal yang tidak dapat dilakukan secara maksimal, seperti tidak adanya interaksi pembelajaran langsung antar siswa (Bhamani et al., 2020), terkendalanya kepemilikan media teknologi sebagai media pembelajaran (Queiros \& Villers, 2016).

Pembelajaran daring ini menjadi sebuah pilihan yang tidak terelakkan bagi institusi pendidikan. Di tengah pandemi Covid-19, metode pembelajaran ini dapat menjadi solusi agar proses belajar mengajar dapat tetap berlangsung. Guru tetap bisa mengajar dan siswa tetap bisa belajar di rumah selama pandemi ini. Pembelajaran daring identik dengan pemanfaatan fitur teknologi berbasis internet, yang sangat bergantung pada ketersediaan teknologi informasi (Asmuni, 2020).

Media online ini memiliki kekurangan jika dibandingkan dengan pembelajaran tatap muka. Dalam pembelajaran daring siswa tidak dapat dikontrol dengan ketat oleh guru mengenai kehadiran siswa dalam pembelajaran. Dalam mengerjakan tugas, siswa dapat langsung menyalin dari internet (Chawinga, 2017). Bahkan siswa tidak mengumpulkan pekerjaan rumah yang diberikan oleh guru.

Pemberian tugas atau pekerjaan rumah merupakan suatu teknik dalam pembelajaran daring yang dapat mengkaitkan antara pembelajaran di rumah dengan peran orang tua dalam pembelajaran. Hasil penelitian Gu dkk. diperoleh bahwa $86 \%$ orang tua berharap memiliki waktu untuk mendampingan anaknya dalam mengerjakan pekerjaan rumah, karena pekerjaan rumah sebagai salah satu alat komunikasi antara orang tua dengan anaknya (Gu et al., 2015). Demikian halnya hasil penelitian Cunha dkk. mengemukakan bahwa orang tua dalam pekerjaan rumah anak-anak mereka sebagai hal yang penting dilakukan untuk meningkatkan kualitas siswa di luar sekolah (Cunha et al., 2015).

Pendampingan ini bukan harus menuntut orang tua mampu menyelesaikan seluruh pekerjaan rumah yang dimiliki oleh anaknya, tetapi keberadaan orang tua di sisi anaknya saat anak tersebut mengerjakan pekerjaan rumah. Orang tua memiliki motivasi tinggi untuk terlibat dalam pekerjaan rumah anak-anak (Silinskas et al., 2013). Ada yang berbeda jenis keterlibatan orang tua di pembelajaran daring, seperti menetapkan aturan, pemantauan orang tua, dan membantu langsung, yang memiliki hubungan yang berbeda dengan prestasi belajar anak.

Demikian juga penelitian yang dilaksanakan di Turki, menyimpulkan bahwa kemitraan antara orang tua dan guru sangat diperlukan. Keterliban orang tua dalam pembelajaran di rumah dibutuhkan untuk semua tingkatan. Orang tua tidak hanya berperan dalam 
prestasi akademik siswa, tetapi juga masalah perilaku siswa. (Erdener \& Knoeppel, 2018).

Namun kenyataannya tidak semua orang tua memiliki cukup waktu di rumah untuk dapat berkumpul dan berkomukasi dengan anaknya. Mereka tenggelam dengan kesibukan work from home atapun bersosial media. Mereka lupa bahwa memiliki anak usia sekolah yang membutuhkan perhatian terutama dalam hal belajar. Berdasarkan fenomena yang ada, kemudian dicoba untuk menemukan jalan keluar dengan menggunakan inovasi penggunaan teknologi dalam pembelajaran daring dengan melibatkan peran orang tua.

Penelitian ini bertujuan untuk: (1) Mengembangkan model pembelajaran daring dengan pendampingan orang tua yang layak digunakan bagi siswa kelas VII SMP Negeri di kota Kisaran; (2) Menilai keefektifan dan kepraktisan model pembelajaran daring dengan pendampingan orang tua yang dikembangkan bagi siswa VII SMP Negeri di kota Kisaran.

\section{METODE PENELITIAN}

Penelitian ini dilaksanakan di SMP Negeri yang ada di kota Kisaran. Pelaksanaan berlangsung pada semester genap tahun ajaran 2019/2020. Populasi pada penelitian ini adalah seluruh siswa kelas VII (tujuh) SMP Negeri di Kisaran yang berjumlah 2.176 orang. Sampel uji coba perorangan melibatkan tujuh orang siswa yang berasal dari satu kelas pada populasi. Pengambilan sampel uji coba perorangan dilakukan dengan teknik purposive sampling. Sampel uji coba kelompok kecil melibatkan dua puluh orang siswa yang berasal dari satu kelas pada populasi. Pengambilan sampel uji coba kelompok kecil dilakukan dengan teknik purposive sampling. Kelas yang dipilih sebagai uji coba kelompok kecil, maka kelas tersebut tidak akan diikutsertakan dalam pengambilan sampel pada uji coba lapangan dan uji coba kelayakan. Sampel uji coba lapangan untuk analisis model pendampingan orang tua berbantuan aplikasi android melibatkan satu kelas eksperimen. Pengambilan sampel uji coba lapangan dilakukan dengan teknik purposive sampling. Sekolah yang terpilih sebagai sampel uji coba lapangan tidak diikutsertakan dalam pengambilan sampel pada uji coba kelayakan.

Pemilihan kelompok sampel diperoleh dari tiap sekolah. Setiap sekolah ditentukan satu kelas sebagai kelompok eksperimen. Pemilihan kelompok eksperimen dari masingmasing sekolah dilakukan dengan teknik purposive sampling dengan pertimbangan pada kelas tersebut seluruh orang tua menggunakan smartphone android. Uji coba kelayakan dilaksanakan dalam bentuk eksperimen semu dengan menggunakan perancangan uji paired sample t-test.

Dalam pelaksanaan model pembelajaran daring dengan pendampingan orang tua, rancangan langkahlangkah (sintaks) yang dikembangkan adalah model pembelajaran SAPTA yaitu sebagai berikut: (1) Schedule (Fase Perencanaan Pembelajaran), (2) Acceptance (Fase Proses Pembelajaran), (3) Performance (Fase Penugasan), (4) Transmit (Fase Penyampaian Informasi), (5) Assistance (Fase Pendampingan Orang Tua).

Sepuluh langkah pelaksanaan strategi dalam penelitian:

1. Research and information collecting; termasuk dalam langkah ini antara lain studi literatur yang berkaitan dengan permasalahan yang dikaji, dan persiapan untuk merumuskan kerangka kerja penelitian; 
2. Planning; termasuk dalam langkah ini merumuskan kecakapan dan keahlian yang berkaitan dengan permasalahan, menentukan tujuan yang akan dicapai pada setiap tahapan, dan jika mungkin/ diperlukan melaksanakan studi kelayakan secara terbatas;

3. Develop preliminary form of product, yaitu mengembangkan bentuk permulaan dari produk yang akan dihasilkan. Termasuk dalam langkah ini adalah persiapan komponen pendukung, menyiapkan pedoman dan buku petunjuk, dan melakukan evaluasi terhadap kelayakan alat-alat pendukung;

4. Preliminary field testing, yaitu melakukan uji coba awal dalam skala terbatas, dengan melibatkan Sampel sebanyak enam sampai dengan dua belas siswa. Pada langkah ini pengumpulan dan analisis data dapat dilakukan dengan cara wawancara, observasi atau angket;

5. Main product revision, yaitu melakukan perbaikan terhadap produk awal yang dihasilkan berdasarkan hasil ujicoba awal. Perbaikan ini sangat mungkin dilakukan lebih dari satu kali, sesuai dengan hasil yang ditunjukkan dalam ujicoba lapangan, sehingga diperoleh draft produk (model) utama yang siap diuji coba lebih luas (uji coba kelayakan);

6. Main field testing, uji coba kelayakan yang melibatkan seluruh Populasi yang telah terwakili oleh Subjek.

7. Operational product revision, yaitu melakukan perbaikan/ penyempurnaan terhadap hasil uji coba lebih luas, sehingga produk yang dikembangkan sudah merupakan desain model operasional yang siap divalidasi;

8. Operational field testing, yaitu langkah uji validasi terhadap model operasional yang telah dihasilkan;

9. Final product revision, yaitu melakukan perbaikan akhir terhadap model yang dikembangkan guna menghasilkan produk akhir (final);

10. Dissemination and implementation, yaitu langkah menyebarluaskan produk/model yang dikembangkan

Pada penelitian ini terdapat dua jenis kuesionet/angket yang digunakan yaitu pada studi pendahuluan, dan pada uji coba penelitian. Secara spesifik kedua jenis instrument tersebut memiliki perbedaan dalam tujuan yang ingin dicapai. Pada studi pendahuluan, daftar pertanyaan yang digunakan bertujuan untuk mengungkap fakta pendampingan belajar yang dilakukan orang tua siswa selama ini. Kuesioner/angket yang digunakan pada uji coba penelitian bertujuan untuk memperoleh data mengenai respon sampel terhadap desain model yang telah diterapkan serta mendeskripsikan hambatan yang ditemui.

\section{HASIL DAN PEMBAHASAN}

Pengaruh pandemi Covid-19 membuat kegiatan pembelajaran berubah signifikan. Pada saat sebelum pandemi siswa mengikuti pembelajaran di sekolah secara teratur dari pagi sampai siang setiap hari, kecuali hari libur. Pembelajaran tatap muka yang dilaksanakan di sekolah membuat siswa lebih disiplin waktu dalam pelaksanaan proses pembelajaran. Selain itu juga guru dapat lebih mudah dalam menjalankan rencana pembelajaran yang telah dirancang, mulai dari persiapan sampai dengan evaluasi. Kondisi ini jauh berbeda dengan pembelajaran yang terjadi di masa pandemi.

Pembelajaran daring yang dilaksanakan pada saat penelitian 
dengan menggunakan menggunakan whatsapp group. Media online ini memiliki kekurangan jika dibandingkan dengan pembelajaran tatap muka. Dalam pembelajaran daring siswa tidak dapat dikontrol dengan ketat oleh guru mengenai kehadiran siswa dalam pembelajaran. Dalam mengerjakan tugas, siswa dapat langsung menyalin dan menempel dari internet (Chawinga, 2017). Bahkan siswa tidak mengumpulkan pekerjaan rumah yang diberikan oleh guru.

Penggunaan whatsapp dalam pembelajaran lebih baik daripada email, SMS, twitter (Boyinbode et al., 2017), namun penggunaan whatsapp group memiliki kelemahan, yaitu: (1) Whatsapp group berada pada siswa, sehingga orang tua tidak dapat mengontrol pembelajaran anaknya terutama pekerjaan rumah. (Sudarsana et al., 2019); (2) Setiap guru membuat whatsapp group, sehingga guru dan siswa memiliki whatsapp group yang banyak; (3) Whatsapp group yang bersifat terbuka (umum), sehingga siswa dapat melihat jawaban dari temannya saat akan mengumpulkan tugas; (4) Jumlah siswa yang banyak dalam setiap kelasnya dapat menyebabkan penggunaan memory telepon pada guru dan siswa yang cukup besar; (5) Guru mengalami kesulitan dalam mendata hasil pekerjaan siswa; (6) Hasil koreksi pekerjaan rumah yang dilakukan guru tidak bersifat rahasia, karena dibagikan dalam whatsapp group; (7) Informasi yang berada dalam satu ruangan, sehingga menimbulkan ketidakteraturan; (8) Tidak semua siswa enggunakan smartphone saat daring untuk pembelajaran namun untuk bermain game dan sosial media.

Adapun langkah-langkah (sintaks) model pembelajaran ini adalah model pembelajaran SAPTA, yaitu:
(1) Schedule (fase perancangan pembelajaran)

1. Sebelum pelaksanaan pembelajaran, guru menyampaikan file materi pembelajaran Matematika untuk dipelajari siswa secara mandiri (sebaiknya dilengkapi dengan video guru mengajar tentang materi tersebut).

2. Guru menyampaikan hal-hal penting dari materi pembelajaran Matematika melalui media pembelajaran online, disarankan menggunakan voice note pada whatsapp group dengan durasi maksimal 5 menit setiap sesi.

3. Guru memberi peluang kepada siswa guna mengajukan pertanyaan, dalam bentuk teks maupun voice note.

4. Guru menjawab pertanyaan siswa.

5. Guru kembali menyampaikan materi dan memberi kesempatan siswa bertanya (sesi berikutnya).

Dalam fase ini guru mendorong siswa supaya lebih aktif saat belajar mandiri dan mengajukan pertanyaan.

(2) Acceptance (fase umpan balik) Untuk mengetahui pemahaman siswa, guru memberikan umpan balik dalam bentuk voice note ataupun soal latihan, dan meminta siswa untuk langsung menjawab pertanyaan guru dalam bentuk voice note ataupun foto hasil pekerjaan yang langsung dikerjakan oleh siswa tersebut.

(3) Performance (fase penugasan)

Fase ini merupakan fase akhir pada pembelajaran online. Guru memberikan tugas/soal yang harus dikerjakan siswa di luar jam belajar Bersama guru. Tugas ini tentukan akan dikerjakan oleh siswa dengan pendamapingan orang tua. 
(4) Transmit (fase penyampaian informasi)

Pada tahap ini guru menginput data tentang aktifitas siswa di kelas online, materi pelajaran, dan pekerjaan rumah yang diberikan kepada siswa saat pembelajaran ke dalam aplikasi pendampingan orang tua dalam belajar. Data ini akan diakses oleh orang tua siswa sebagai bahan masukan dalam mendampingi anaknya belajar.

(5) Assistance (fase pendampingan orang tua)

Pada fase ini siswa mengerjakan tugas yang diberikan oleh guru didampingi oleh orang tua dengan memperhatikan hal-hal berikut: (a) siswa didampingi orang tua dan diberikan dorongan sehingga anak mau bekerja, (b) dikerjakan sendiri oleh siswa tidak menyuruh orang lain mengerjakannya, (c) orang tua dapat memperhatikan arahan yang diberikan guru pada aplikasi pendampingan orang tua dalam belajar, (d) Diakhir pendampingan orang tua memberikan pemberitahuan kepada guru bahwa telah dilakukan pendampingan belajar melalui aplikasi.

Pada pelaksanaan perlakuan di kelas eksperimen, orang tua dilibatkan dalam pembelajaran daring terutama dalam mengecek pekerjaan rumah siswa. Orang tua dituntut untuk dapat mendampingi anaknya dalam belajar terutama mendampingi anaknya saat menyelesaikan pekerjaan rumah yang diberikan oleh guru. Orang tua tidak dituntut untuk mampu menyelesaikan seluruh soal yang diberikan, tetapi minimal mendampingi dan memberi semangat saat anaknya belajar di rumah.

Selain pendampingan anak belajar di rumah, dalam kelas eksperimen orang tua juga memperoleh informasi dari guru di sekolah tentang pekerjaan rumah yang diberikan oleh guru. Informasi diberikan melalui aplikasi pendampingan orang tua dalam belajar yang sebelumnya telah diberikan pihak sekolah kepada masing-masing orang tua. Dengan adanya informasi ini orang tua lebih dapat mengontrol pembelajaran anaknya di rumah.

Adapun hasil-hasil dari uji coba dari produk yang dikembangkan dapat dilihat pada Tabel 1.

Tabel 1. Hasil uji kelayakan produk

\begin{tabular}{lcc}
\hline \multicolumn{1}{c}{$\begin{array}{l}\text { Indikator } \\
\text { Penilaian }\end{array}$} & Persentase & Kriteria \\
\hline $\begin{array}{l}\text { Ahli Model } \\
\text { Pembelajaran }\end{array}$ & $77,86 \%$ & Baik \\
$\begin{array}{l}\text { Ahli Desain } \\
\text { Pembelajaran }\end{array}$ & $79,17 \%$ & Baik \\
$\begin{array}{l}\text { Ahli Media } \\
\text { Pembelajaran }\end{array}$ & $84,38 \%$ & Sangat Baik \\
$\begin{array}{l}\text { Uji Coba } \\
\text { Perorangan }\end{array}$ & $85,71 \%$ & Sangat Baik \\
$\begin{array}{l}\text { Uji Coba } \\
\text { Kelompok }\end{array}$ & $90,17 \%$ & Sangat Baik \\
Kecil & & \\
Uji Coba & $91,25 \%$ & Sangat Baik \\
Lapangan & $\mathbf{8 4 , 7 5 \%}$ & Sangat Baik \\
\hline
\end{tabular}

Dari hasil validasi ahli dan uji coba penelitian terhadap mata pelajaran Matematika (tabel 1) diperoleh rata-rata presentase sebesar 84,75\%. Dapat disimpulkan bahwa model pembelajaran daring dengan pendampingan orang tua yang dikembangkan pada mata pelajaran Matematika mendapat nilai "sangat baik" dari hasil semua proses validasi dan uji coba. Dengan demikian model pembelajaran daring dengan pendampingan orang tua tersebut "sangat layak" digunakan dalam proses pembelajaran terutama pada pembelajaran daring. 
DOI: https://doi.org/10.24127/ajpm.v10i3.3789

Model pembelajaran daring dengan pendampingan orang tua yang dalam penelitian ini disebut dengan model SAPTA dikembangkan dengan mengacu pada beberapa model pembelajaran dan pendampingan yaitu: model pendam-pingan self assessment, metode resitasi, model flipped learning, dan model pendampingan partisipasif. Dalam pengaplikasiannya model pembelajaran SAPTA memiliki beberapa kelebihan dalam pelaksanaan pembelajaran daring.

Terjadi komunikasi antara guru dan orang tua. Pada masa pandemi yang mewajibkan pembelajaran secara daring, komunikasi antara guru dan orang tua nyaris terputus. Padahal komunikasi antara guru dan orang tua sangat dibutuhkan guna memantau perkembangan belajar dan karakter anak (Arini, 2020), Keterlibatan orang tua dalam pekerjaan siswa dapat menekan kegagalan pembelajaran siswa dari 15,8\% menjadi 9,3\% (Kraft \& Rogers, 2015). Sejalan dengan hal tersebut, hubungan antara sekolah dan keluarga harus diperkuat, karena orang tua sangat penting untuk didorong anak-anak mereka dan mendukung mereka dalam mengatur pekerjaan rumah mereka (Costa et al., 2016) Hasil penelitian tersebut mendukung penggunaan model pembelajaran SAPTA dalam melaksanakan pembelajaran daring.

Hasil penelitian Can mene-mukan bahwa guru harus memberikan informasi yang tepat tentang kemajuan siswa serta informasi lainnya (Can, 2016). Di Nepal, sebagian besar sekolah menggunakan buku catatan yang disebut "buku komunikasi atau buku harian sekolah sebagai alat komunikasi dengan orang tua". Sistem tradisional dan paling terkenal ini masih digunakan di banyak negara bagian. Guru kelas menuliskan catatan atau pemberitahuan kepada orang tua tentang informasi kegiatan saat ini atau peristiwa yang akan datang. Hasil analisis data dari penelitian menunjukkan bahwa $82,2 \%$ pandangan orang tua tentang penggunaan aplikasi seluler untuk meningkatkan lingkungan pendi-dikan terbukti positif dan bermanfaat (Can, 2016).

Penggunaan aplikasi android dalam penelitian ini lebih menjaga kerahasiaan perkembangan belajar dan nilai masing-masing siswa, sehingga dapat menjaga psikologis anak dan orang tua.

Orang tua dapat mengetahui pekerjaan rumah anaknya. Hasil penelitian Dong dkk. mengemukakan bahwa dari hasil penelitian mereka $92,7 \%$ orang tua di China merasa pesimis dalam mendampingi anaknya belajar di masa pandemic Covid-19. Kondisi ini terjadi karena orang tua merasa tidak terlatih atau siap menghadapi pembelajaran daring. (Dong et al., 2020)

Kolaborasi antara orang tua dan anak dalam menyelesaiakan peker-jaan rumah adalah cara yang bermanfaat untuk mendukung perkembangan siswa. Hasil penelitian Hutchison dkk. Menyatakan bahwa menghubungkan dunia rumah dan sekolah, terbukti dalam kebijakan global tentang keterlibatan keluarga dan inisiatif kemitraan antara guru dan orang tua untuk mendukung pendidikan anak-anak dipandang sebagai dimensi kunci keberhasilan akademis. (Hutchison et al., 2020)

Hal ini menuntut upaya bersama dari guru dan orang tua dalam memahami peran dan tantangan mereka yang berbeda dan mengembangkan diri dengan belajar dari satu sama lain. Perspektif guru menunjukkan bahwa mereka melihat perkembangan siswa yang positif melalui keterlibatan orang 
tua, dan semakin banyak orang tua yang mencoba menghabiskan lebih banyak waktu dengan anak-anak mereka di rumah untuk mempelajari keteram-pilan baru. Dengan bekerjasama dengan guru, orang tua menjadi lebih akrab dengan prinsip-prinsip perkem-bangan anak (misalnya, dorongan positif di rumah) (Li, Li, \& Yin, 2015).

Siswa merasa nyaman saat didampingi oleh orang tua saat belajar di rumah. Tahun 2011 Coalition for Equal Access to Education (CEAE) di Canada telah mengembangkan program Helping Children Learn at Home, yaitu program yang mendu-kung orang tua dalam menciptakan lingkungan belajar yang sehat di rumah. CEAE mengemukakan bahwa lebih baik menangani kebutuhan belajar anak-anak di rumah dan berkontribusi pada proses pengam-bilan keputusan di sekolah dan masyarakat, turut mempengaruhi keberhasilan pendidikan anak-anak. (Jasinski, 2012)

Pada masa pandemi Covid-19 dengan menggunakan pembelajaran daring menuntut siswa belajar mandiri tanpa banyaknya frekuensi pembelajaran yang diberikan oleh guru. Kondisi ini tentunya membuat orang tua harus mampu menggantikan peran guru sebagai motivator dan pendamping dalam belajar di rumah. Orang tua harus menyisihkan waktu mereka untuk mendampingi anaknya belajar, tanpa harus men-desak atau menghakimi (Davidovitch \& Yavich, 2017). Pendampingan orang tua membantu dapat meningkatkan kepercayaan anak dalam mengerjakan pekerjaan rumah, selain itu juga meningkatkan intensitas hubungan orang tua dan anak dalam berkomunikasi di rumah (Abthoki, 2019). Selain itu juga keterlibatan orang tua dalam pekerjaan rumah dapat mempenga-ruhi kinerja siswa (Núñez et al., 2017). Dari hasil penelitian diperoleh bahwa $82,0 \%$ orang tua yang membantu pekerjaan rumah terbukti sangat positif dan memberikan kontribusi bagi perkembangan anakanak serta peningkatan kinerja sekolah mereka (Costa et al., 2016).

Penggunaan model pembelajaran daring dengan pendampingan orang tua membuat mereka merasa percaya diri dalam mendampingi anaknya belajar di rumah. Hal ini disebabkan, orang tua dapat mengetahui materi pembelajaran atau tugas yang diberikan guru untuk anaknya melalui aplikasi yang dimilikinya. Dengan kepercayaan diri oleh orang tua dalam mendampingi anaknya belajar di rumah, membuat siswa (anak) merasa nyaman belajar.

Pekerjaan rumah di koreksi oleh guru. Hasil penelitian Zhang dkk. di China dengan menggunakan metode Automated Writing Evaluation (AWE) programmes diketahui bahwa umpan balik yang diberikan oleh guru sangat mempengaruhi reaksi emosional siswa (Zhang, Z. (Victor), \& Hyland, 2018). Hasil penelitian Costa dkk., yang menyatakan guru yang selalu melakukan koreksi pekerjaan rumah yang ditugaskan, dapat meningkatkan motivasi belajar siswa (Costa et al., 2016).

Carless dkk. mengemukakan bahwa kegiatan umpan balik siswa akan berhasil jika guru memberikan kondisi kurikulum yang sesuai untuk partisipasi siswa aktif, memberikan bimbingan yang memadai, pem-binaan dan pemodelan. Pemodelan pemberian/ penerimaan umpan balik yang dilakukan oleh guru merupakan bagian terpenting dalam proses pembelajaran (Carless, D., \& Boud, 2018).

Didukung oleh hasil penelitian Dawson dkk. yang dilakukan di Australia diketahui bahwa $84 \%$ siswa menulis bahwa komentar umpan balik 
berkualitas tinggi membuat umpan balik menjadi efektif, terutama komentar yang dapat digunakan, terperinci, memper-timbangkan pengaruh, dan dipersonalisasi untuk pekerjaan siswa sendiri (Dawson et al., 2019).

Dengan menggunakan model pembelajaran daring dengan pendampingan orang tua guru harus memberikan umpan balik terhadap pekerjaan siswa yang telah dikumpulkan. Hal ini dikarenakan terdapat jadwal yang harus dipenuhi oleh siswa dalam menyelesaikan pekerjaan rumah dan guru yang memberikan umpan balik terhadap pekerjaan siswa tersebut.

Siswa tepat waktu dalam mengerjakan pekerjaan rumah. Siswa yang mengerjakan pekerjaan rumah tepat waktu dapat meningkatkan kemampuan kinerja mereka. Dari hasil penelitian mereka di Portugal, siswa hanya perlu waktu rata-rata tiga puluh menit hingga satu jam dalam menyelesaikan pekerjaan rumah. Artinya siswa tidak perlu banyak menyita waktu untuk menyelesaikan pekerjaan rumah mereka (Costa et al., 2016).

Ketepatan waktu dalam menyelesaikan pekerjaan rumah juga merupakan latihan dalam manajemen waktu. Selain itu mengerjakan tugas tepat waktu artinya tidak menunda atau menumpuk pekerjaan rumah yang dampaknya dapat menimbulkan stress atau menurunnya tingkat produktif (Valle et al., 2019)

Dengan penggunaan model pembelajaran daring dengan pendampingan orang tua ini siswa diharuskan tepat waktu dalam menyelesaikan pekerjaan rumah, dan mendapat kontrol penuh oleh orang tuanya. Kondisi ini dapat menyebabkan siswa belajar manajemen waktu, disiplin, dan bertanggungawab. Hal tersebut diperlukan siswa sebagai salah satu kunci keberhasilan (Sujarwo, 2020).

Materi pelajaran langsung dishare oleh guru. Dalam model pembelajaran daring dengan pendampingan orang tua materi pelajaran langsung dishare oleh guru, sehingga siswa atau orang tua tidak perlu repot dalam mencari referensi dalam belajar di rumah. Dalam pendampingan belajar di rumah orang tua tidak perlu terlalu repot untuk mencari referensi yang sesuai dengan materi yang sedang dipelajari anaknya, sehingga dapat membantu orang tua dalam membimbing anaknya walaupun memiliki keterbatasan pengetahuan (Purwanto \& Kurnasih, 2018).

Hasil penelitian Ahmar dkk. menyatakan bahwa $64,52 \%$ responden sangat menyukai materi yang disimpan di database (Ahmar \& Rahman, 2017).

Materi tersimpan di aplikasi. Aplikasi android sangat mem-bantu terutama dalam kepraktisan dalam penggunaan, karena dapat digunakan secara mobile. Media pembelajaran mobile berbasis android menawarkan pengalaman baru bagi siswa dengan menyimpan materi pelajaran di database (Cahyana et al., 2018).

Demikian halnya dengan penggunaan android pada model pembelajaran daring dengan pendampingan orang tua, materi pelajaran tersimpan di database aplikasi sehingga dapat dibuka dan dipelajari kapan saja. Saat mengerjakan pekerjaan rumah siswa dan orang tua dapat kembali memahami materi pelajaran yang dishare oleh gurunya.

Kondisi ini sejalan dengan hasil penelitian Ambaryati mengungkapkan bahwa semakin intens pendampingan belajar orang tua yang diberikan kepada anak, akan memberikan hasil belajar yang lebih baik (Ambaryanti, 2013). 
Penelitian ini menghasilkan model pembelajaran dengan pendampingan orang tua berbantuan aplikasi android beserta perangkat pendukungnya yang layak diimplementasikan untuk mendukung kegiatan pembelajaran terutama pembelajaran daring. Perangkat pembelajaran yang dihasilkan adalah aplikasi android pendampingan orang tua dalam belajar, buku model, buku panduan guru, dan buku panduan orang tua.

\section{KESIMPULAN DAN SARAN}

Berdasarkan pembahasan dalam penelitian ini dapat diambil simpulan bahwa produk model pembelajaran yang dikembangkan menggunakan sintaks model pembelajaran SAPTA (Schedule, Acceptance, Performance, Transmit, Assistance) layak digunakan pada pelajaran Matematika bagi siswa kelas VII SMP Negeri di kota Kisaran.

Dari hasil penelitian, disarankan kepada guru agar lebih mengarahkan siswa tidak hanya pada pemahaman materi, tetapi juga bagaimana siswa mampu mengembangkan diri dalam menyelesaikan soal-soal yang berkaitan dengan materi yang tingkat taksonomi yang lebih tinggi.

\section{DAFTAR PUSTAKA}

Abthoki, A. (2019). Peran Ibu Dalam Kegiatan Pendampingan Belajar Anak Melalui Prinsip Indiviual Learning-Centered. Egalita, Jurnal Kesetaraan Dan Keadilan Gender, 4(2), 168-177.

Ahmar, A. S., \& Rahman, A. (2017). Development of teaching material using an Android. Global Journal of Engineering Education, 19(1), 72-76.

Ambaryanti, R. (2013). Hubungan Intensitas Pendampingan Belajar Orang Tua Dengan Kualitas Hasil
Belajar Siswa di RA Al-Islam Mangunsari 02 Semarang Tahun Pelajaran 2011/2012. Indonesian Journal of Early Childhood Education Studies, 2(2), 43-49.

Arini, N. W. (2020). Pentingnya Komunikasi Guru Dengan Orang Tua Dalam Membagun Karakter Peserta Didik. Guna Widya: Jurnal Pendidikan Hindu, 7(2), 154-159.

Asmuni. (2020). Problematika Pembelajaran Daring di Masa Pandemi Covid-19 dan Solusi Pemecahnnya. Jurnal Paedagogy: Jurnal Penelitian Dan Pengembangan Pendidikan, 7(4), 281-288.

Bhamani, S., Makhdoom, A. A., Bharuchi, V., Ali, N., Kaleem, S., \& Ahmed, D. (2020). Home Learning in Times od COVID: Experiences of Parents. Journal of Education Development, 7(1), 926.

Boyinbode, O. K., Agbonifo, O. C., \& Ogundare, A. (2017). Supporting mobile learning with WhatsApp based on media richness. Circulation in Computer Science, 2(3), 37-46.

Cahyana, U., Paristiowati, M., \& Fauziyah, S. (2018). Development of Android-Based Mobile learning media on Atomic Structure and Periodic Table. IOP Conference Series: Materials Science and Engineering, 434(1).

Can, M. H. (2016). Use of Mobile Application: Means of Communication Between Parents and Class Teacher. World Journal on Educational Technology, 8(3), 252-257.

Carless, D., \& Boud, D. (2018). The development of student feedback literacy: enabling uptake of 
DOI: https://doi.org/10.24127/ajpm.v10i3.3789

feedback. Assessment \& Evaluation in Higher Education, 43(8), 1315-1325.

Chawinga, W. D. (2017). Taking Social Media To A University Classroom: Teaching and Learning Using Twitter and Blogs. International Journal of Educational Technology in Higher Education, 14(3).

Costa, M., Cardoso, A. P., Lacerda, C., Lopes, A., \& Gomes, C. (2016). Homework in Primary Education from the Perspective of Teachers and Pupils. Procedia - Social and Behavioral Sciences, 217, 139148.

Cunha, J., Rosário, P., Macedo, L., Nunes, A. R., Fuentes, S., \& Pinto, R. (2015). Concepciones de los padres sobre su implicación en los deberes en la escuela primaria. Psicothema, 27(2), 159-165.

Davidovitch, N., \& Yavich, R. (2017). Views of Students, Parents, and Teachers on Homework in Elementary School. International Education Studies, 10(10), 90.

Dawson, P., Henderson, M., Mahoney, P., Phillips, M., Ryan, T., Boud, D., \& Molloy, E. (2019). What makes for effective feedback: Staff and student perspectives. Assessment \& Evaluation in Higher Education, 44(1), 25-36.

Dong, C., Cao, S., \& Li, H. (2020). Young children's online learning during COVID-19 pandemic: Chinese parents' beliefs and attitudes. Children and Youth Services Review, 118, 105440.

Erdener, M. A., \& Knoeppel, R. C. (2018). Parents' perceptions of their involvement in schooling. International Journal of Research in Education and Science (IJRES), 4(1).
Gu, H., Yin, L., \& Li, J. (2015). Making Homework a Catalyst of TeacherParents-Children's Collaboration: A Teacher Research Study from an Elementary School in China. International Journal About Parents in Education, 9(1), 4765.

Hutchison, K., Paatsch, L., \& Cloonan, A. (2020). Reshaping homeschool connections in the digital age: Challenges for teachers and parents. E-Learning and Digital Media, 17(2), 167-182.

Kraft, M. A., \& Rogers, T. (2015). The underutilized potential of teacherto-parent communication: Evidence from a field experiment. Economics of Education Review, 27, 49-63.

Núñez, J. C., Epstein, J. L., Suárez, N., Rosário, P., Vallejo, G., \& Valle, A. (2017). How do student prior achievement and homework behaviors relate to perceived parental involvement in homework? Frontiers in Psychology, 8, 1217.

Purwanto, S. E., \& Kurnasih, M. D. (2018). Pendampingan Orang Tua Membimbing Matematika Anak di Jatiluhur, jatiasih, Kota Bekasi. Jurnal Solma, 1(1), 121-127.

Queiros, D. R., \& Villers, M. R. (2016). Online Learning in a South African Higher Education Institution: Determining the Right Connections for the Student. International Review of Research in Open and Distribured Learning, 17(5), 165-185.

Silinskas, G., Niemi, P., Lerkkanen, M. K., \& Nurmi, J. E. (2013). Childrens poor academic performance evokes parental homework assistance-but does it help? International Journal of 
DOI: https://doi.org/10.24127/ajpm.v10i3.3789

Behavioral Development, 37(1), 44-56.

Sudarsana, I. K., Putra, I. B. M. A., Astawa, I. N. T., \& Yogantara, I. W. L. (2019). The use of Google classroom in the learning process. Journal of Physics: Conference Series, 1175(1), 012165.

Sujarwo, H. (2020). Pengaruh Pemberian Tugas Pekerjaan Rumah (PR) dan Ketersediaan Waktu Belajar Terhadap Prestasi Belajar Siswa Pada Mata Pelajaran Pendidikan Agama Budha di SMP Negeri 2 Kaloran. BAHUSACCA: Pendidikan Dasar Dan Manajemen Pendidikan, 1(1), 32-43.

Valle, A., Piñeiro, I., Rodríguez, S., Regueiro, B., Freire, C., \& Rosano, P. (2019). Time spent and time management in homework in elementary school students: A person-centered approach. Psicothema, 31(4), 422-428.

Zhang, Z. (Victor), \& Hyland, K. (2018). Student engagement with teacher and automated feedback on L2 writing. Assessing Writing, 36, 90-102. 